\title{
PENGARUH STRATEGI PEMBELAJARAN DAN KEMAMPUAN BERPIKIR VERBAL TERHADAP HASIL BELAJAR BAHASA INGGRIS
}

\author{
Syahran Yusuf \\ Guru SMP Negeri 1 Selesai, Sumatera Utara \\ syahran.y@gmail.com
}

\begin{abstract}
Abstrak: Penelitian ini bertujuan untuk mengetahui perbedaan pengaruh strategi pembelajaran dan kemampuan berpikir verbal terhadap hasil belajar siswa pada mata pelajaran Bahasa Inggris. Strategi pembelajaran yang digunakan adalah strategi pembelajaran Kontekstual dan strategi pembelajaran ekspositori, sedangkan kemampuan berpikir verbal yang dimaksud adalah kemampuan berpikir verbal tinggi dan kemampuan berpikir verbal rendah. Hipotesis penelitian diuji dengan menggunakan Anava 2 jalur, yang sebelumnya terlebih dahulu dilakukan uji persyaratan analisis data yaitu uji normalitas dengan uji Lilliefors dan uji homogenitas varians dengan uji Bartlett dan Uji Fisher. Penelitian ini menyimpulkan bahwa : (1) hasil belajar Bahasa Inggris siswa yang dibelajarkan dengan strategi pembelajaran kontekstual lebih tinggi dibandingkan dengan siswa yang dibelajarkan dengan strategi pembelajaran ekspositori; (2) siswa yang memiliki kemampuan berpikir verbal tinggi memperoleh hasil belajar Bahasa Inggris yang lebih tinggi dibandingkan dengan siswa yang memiliki kemampuan berpikir verbal rendah; (3) terdapat interaksi antara strategi pembelajaran dan kemampuan berpikir verbal dalam mempengaruhi hasil belajar Bahasa Inggris siswa.
\end{abstract}

Kata Kunci: strategi pembelajaran konstekstual dan ekspositori, kemampuan berpikir verbal, hasil belajar, bahasa inggris.

Abstract: These study were aimed to find out the effect of using learning strategy and verbalism thinking achievement toward the result of learning English language. The learning strategy used were contextual and expository learning strategy, while verbalism thinking achievement meant here were high verbalism thinking achievement and low verbalism thinking achievement. The hypothesis were tested by using two-ways Anova, while normality test using Liliefors test and homogeneity test variants using Bartlett and Fisher test. The hypothesis test result showed that: (1) the students' achievement on learning English language taught by contextual learning strategy is higher than the one with expository learning strategy; (2) the students having high verbalism thinking achievement is higher than the one having low verbalism thinking achievement; (3) there is an interaction between contextual learning strategy and verbalism thinking achievement in effecting the students' learning English language result.

Keywords: contextual and expository learning strategy, verbalism thinking achievement, result of learning, english lenguage

\section{PENDAHULUAN}

Salah satu tujuan penyelenggaraan proses belajar adalah untuk tercapainya tujuan pembelajaran untuk keberhasilan siswa dalam belajar, baik dalam mata pelajaran secara khusus, maupun pendidikan secara umum. Untuk mewujudkan fungsi pendidikan sebagai wahana sumber daya manusia, maka perlu dikembangkan iklim belajar mengajar yang konstruktif bagi berkembangnya suasana, kebiasaan, dan strategi belajar mengajar juga dilandasi dengan pemahaman tentang ilmu pengetahuan dan teknologi serta implikasinya dalam kegiatan belajar mengajar bagi para guru di sekolah.

Dalam penyusunan Kurikulum 2004, semua materi diformulasikan sedemikian rupa dengan lebih menekankan pada penguasaan materi dan didukung oleh strategi pembelajaran yang sesuai serta sarana pendukung kegiatan pendidikan lainnya. Salah satu materi pelajaran pokok dalam kurikulum 2004 yang berbasis kompetensi adalah mata pelajaran bahasa Inggris, dan standar kompetensi yang diharapkan dimiliki oleh siswa lulusan Sekolah Menengah Pertama (SMP) dalam mempelajari 
bahasa Inggris adalah: (1) mampu mendengarkan dan memahami beragam wacana lisan bahasa Inggris, (2) mampu mengungkapkan pikiran, pendapat gagasan, dan perasaan dalam berbagai bentuk wacana lisan bahasa Inggris, (3) mampu membaca dan memahami beragam teks dengan berbagai cara membaca tulisan bahasa Inggris, dan (4) mampu mengekspresikan berbagai pikiran, gagasan, pendapat dan perasaan dalam berbaga ragam tulisan bahasa Inggris (Departemen Pendidikan Nasional, 2004).

Bahasa merupakan alat komunikasi manusia untuk mengungkapkan berbagai keinginan dan kebutuhan di dalam kehidupan. Dari sejak lahir hingga menjelang usia tua manusia akan selalu mengembangkan kemampuan berbahasa agar dapat melakukan komunikasi dengan manusia lain. Pateda (1994) mengemukakan bahwa bahasa adalah bunyibunyian yang bermakna. Sedangkan Irianto (2000) menyatakan bahwa bahasa merupakan kemampuan untuk berkomunikasi dengan orang lain, di mana pikiran perasaan dinyalakan dalam bentuk lambang atau simbol untuk mengungkapkan suatu pengertian.

$$
\text { Selanjutnya Tarigan }
$$

menjelaskan bahwa kemampuan berbahasa merupakan kemampuan seseorang mengenai kaidah-kaidah suatu bahasa, dalam hal ini meliputi kemampuan untuk menciptakan dan memahami kalimat termasuk kalimat yang belum pernah didengar sebelumnya. Lebih lanjut dikemukakan oleh Tarigan (1993) kemampuan berbahasa memiliki empat komponen yang saling berhubungan erat yaitu menyimak, berbicara, membaca dan menulis. Senada dengan pendapat di atas Oliver dan Bowler (1994) mengemukakan bahwa kemampuan berbahasa menjadi dasar terhadap seluruh keahlian dibutuhkan untuk belajar, seperti kemampuan membaca, mengucapkan, dan kemampuan menulis. Melalui bahasa seseorang dapat membuka cakrawala pengetahuan, mengerti pembicaraan orang lain, dan mengungkapkan apa yang dirasakannya.

Proses pembelajaran bahasa Inggris bertujuan untuk mendapatkan pengetahuan tentang membaca (to read), menulis (to write), berbicara (to speak), mendengar (to listen). Dari tujuan pembelajaran bahasa Inggris tersebut di atas, maka secara philosophy Kate (1966) mengemukakan bahwa: "It is that are which seeks to leam •what can be learned about conceptual knowledge and communicated in language. According by, the basic premise of philosophy of language is that there is a strong relation between the form and content of conceptualization. The special task of philosophy of language is therefore, to explore this relation and make what ever inferences about structure of conceptual knowledge can be made of the basic of what is known about the structure of language”.

Dalam rangka mengatasi persoalan perolehan hasil balajar bahasa Inggris SMP Negeri 1 Selesai yang masih relatif rendah, berbagai upaya telah dilakukan untuk meningkatkan kemampuan dan pemahaman siswa. Upaya-upaya ini dilakukan oleh berbagai pihak, baik guru pengajar, maupun pihak sekolah, antara lain melaksanakan dan mengikuti seminar-seminar, pendidikan dan pelatihan relevan yang berkenaan dengan peningkatan kualitas pembelajaran bahasa Inggris, baik yang dilaksanakan di lingkungan atau di luar sekolah. Meskipun berbagai upaya telah dilakukan untuk meningkatan hasil belajar, namun sejauh ini hasil belajar bahasa Inggris tersebut masih tetap rendah dan tidak menunjukkan adanya peningkatan yang cukup berarti (signifikan).

Menurut pengamatan penulis, proses pembelajaran yang dilakukan oleh guru di SMP Negeri 1 Selesai masih cenderung menggunakan satu strategi pembelajaran saja. Guru mendominasi proses belajar mengajar, dan kurang memvariasikan strategi pembelajaran dalam kegiatan pembelajaran. Siswa kurang diberdayakan dalam menemukan dan memenuhi kebutuhan-kebutuhan belajar siswa. Disamping itu, guru juga tidak memperhatikan karakteristik siswa. Salah satu karakteristik siswa adalah kemampuan berpikir verbal. Dalam suatu proses belajar mengajar, seorang guru hendaknya mampu mengetahui dan memahami kemampuan berpikir verbal siswa, agar guru dapat menyesuaikan, menyusun dan membuat materi ajar dan strategi pembelajaran yang relevan untuk membantu dan mengarahkan kesiapan siswa untuk mengikuti pembelajaran.

Dilihat dari proses belajar mengajar, strategi pembelajaran merupakan proses bimbingan terhadap anak didik dan penciptaan kondisi belajar murid secara aktif. Selanjutnya Romizowski (1981) mengemukakan bahwa setiap strategi pembelajaran yang dikembangkan selalu mencerminkan posisi teoritis yang dianut, tentang bagaimana 
seharusnya pembelajaran itu dilaksankan. Hamalik (1993) mendefenisikan strategi belajar-mengajar sebagai system menyeluruh yang terdiri dan sejumlah komponen, yaitu komponen masukan (input), komponen proses dan komponen produk (output). Strategi pembelajaran dalam rangka pengembangan kognitif dan aktivitas anak didik, merupakan hal terpenting yang harus diperhatikan. Bila strategi pembelajaran dapat membangkitkan atau mendorong timbulnya aktivitas anak didik, maka proses belajar merekapun akan lebih banyak terlaksana dan dengan demikian hasil belajarnya akan lebih baik

Pembelajaran kontekstual atau

Contekstual Teaching and Learning (CTL) adalah konsep belajar yang membantu guru untuk mengaitkan antara materi yang diajarkannya dengan situasi nyata siswa. Konsep belajar ini mempunyai landasan filosofi konstruktivisme serta berpandangan bahwa belajar akan lebih bermakna jika anak "menemukan sendiri" apa yang dipelajarinya, bukan "mengetahuinya" dari orang lain. Dengan demikian, hasil pembelajaran diharapkan lebih bermakna bagi siswa, karena proses pembelajaran berlangsung alamiah dalam bentuk kegiatan siswa adalah bekerja dan mengalami, bukan transfer pengetahuan dari guru ke siswa (Kasihani, 2002). Dalam pembelajaran berbasis kontekstual, strategi pembelajaran lebih dipentingkan daripada hasil, sehingga diharapkan siswa dapat mengalami dan memahami sendiri apa makna belajar, apa manfaatnya dan bagaimana mencapainya, sehingga siswa dapat menyadari bahwa pelajaran tersebut berguna bagi hidupnya nanti.

Gredler (1994) menjelaskan bahwa pemodelan adalah tingkah laku yang dipertunjukkan atau didemonstrasikan sebagai stimulus untuk belajar dan tugas utama model adalah menyampaikan informasi. Suatu model ialah kumpulan stimulus yang tersusun sedemikian rupa, sehingga seseorang dapat memetik sari dan berpengaruh pada informasi pokok yang dibawakan oleh peristiwa-peristiwa Lingkungan tanpa perlu menunjukkan perbuatan yang kasat mata. Tujuan utama dalam proses belajar menggunakan pemodelan adalah kemampuan seseorang untuk meniru tingkah laku dari model, melalui proses pengamatan, dapat diputuskan tingkah laku mana yang akan ditiru dan dilaksanakan pada diri orang tersebut.
Strategi pembelajaran ekspositori adalah strategi pembelajaran yang menekankan kepada proses penyampaian materi secara verbal dari seorang guru kepada sekelompok siswa dengan maksud agar siswa dapat menguasai materi perkuliahan secara optimal. Ross \& Kyle dalam Sanjaya (2006) menamakan strategi ekspositori ini dengan istilah strategi pembelajaran langsung (direct insruction), karena dalam strategi ini materi perkuliahan disampaikan langsung oleh guru, dan siswa tidak dituntut untuk menemukan sendiri materi itu, dan materi perkuliahan seakan-akan sudah jadi atau telah dipersiapkan oleh guru.

Berdasarkan hasil penelitian Ross \& Kyle dalam Sanjaya (2006), strategi ini sangat efektif untuk mengajarkan konsep dan keterampilan untuk anak-anak yang memiliki kemampuan kurang (low achieving students), (h) jika lingkungan tidak mendukung untuk menggunakan strategi yang berpusat pada siswa, misalnya tidak adanya sarana dan prasarana yang dibutuhkan, dan (i) jika guru tidak memiliki waktu yang cukup untuk menggunakan pendekatan yang berpusat pada siswa.

Setiap makhluk hidup memiliki cara tertentu dalam berkomunikasi dengan sesamanya. Manusia biasanya melakukan komunikasi dengan menggunakan bahasa. Menurut Vinacke (1974), kemampuan berbicara membutuhkan kemampuan menggunakan intelektual dalam berbagai situasi. Pikiran yang juga didasari oleh daya imajinasi penting dalam memecahkan atau menyelesaikan masalahmasalah yang dihadapi. Karena adanya kemampuan berbahasa dan intelektual membuat manusia terutama anak didik mampu mengembangkan bahasa sesuai dengan konteks dan situasi. Crashen (1982) mengemukakan bahwa bahasa dikuasai melalui pemerolehan dan belajar. Pemerolehan biasanya dikaitkan dengan penguasaan bahasa ibu secara alamiah, sedangkan belajar dikaitkan dengan penguasaan bahasa selain bahasa ibu dengan usaha sadar, biasanya dari guru, artinya melalui pendidikan.

Bakry (2001), mendefinisikan berpikir sebagai proses bekerjanya akal dalam menelaah sesuatu, dan dasil kerja dari akal tersebut dapat diketahui apabila dinyatakan dalam bentuk bahasa Kegiatan berpikir manusia dalam kehidupannya telah dimulai dari sejak kecil. Menurut Hasan (1994), dalam struktur tubuh manusia ada yang disebut dengan otak dan eksistensi otak tersebut adalah untuk berpikir. 
Ini berarti, otak yang difungsikan secara baik dan benar disebut berpikir.

Dari uraian di atas, dapat dipahami bahwa pikiran dan bahasa akan terwujud melalui kemampuan berpikir verbal anak didik dan hal-hal ini merupakan dasar anak didik dalam mengutarakan atau menyusun suatu konsep dan mengemukakan pikirannya kepada orang lain. Menurut Nunnally (1970), faktor verbal ada dua macam, yaitu kemampuan berpikir verbal dan kelancaran verbal. Kemampuan berpikir verbal sangat diperlukan berkenaan dengan kemampuan untuk dapat mengarang dan berbicara, sedangkan kelancaran verbal berkenaan dengan kemampuan menghasilkan kata-kata dan kalimat-kalimat secara tepat.

Rumusan masalah pada penelitian ini adalah: (1) Apakah hasil belajar bahasa Inggris siswa yang diajar dengan strategi pembelajaran kontekstual lebih tinggi dari siswa yang diajar dengan strategi pembelajaran ekspositori, (2) Apakah siswa yang memiliki kemampuan berpikir verbal tinggi memperoleh hasil belajar bahasa Inggris yang lebih tinggi dari siswa yang memiliki kemampuan berpikir verbal rendah, dan (3) Apakah ada interaksi antara strategi pembelajaran dan kemampuan berpikir verbal dalam mempengaruhi hasil belajar bahasa Inggris siswa?

\section{METODE}

Penelitian ini dilakukan di SMP Negeri 1 Selesai. Pelaksanaan penelitian diawali dengan melakukan peninjauan ke lokasi penelitian untuk mengetahui tentang keadaan jumlah kelas dan siswa kelas VIII. Sedangkan untuk menguji hipotesis penelitian digunakan teknik statistik inferensial yaitu dengan teknik analisis varians Anava dua jalur (desain factorial $2 \times 2$ ) dengan taraf signifikan $5 \%$ atau 0,05 . Sebelum data hasil penelitian dianalisis menggunakan teknik statistik infrensial, terlebih dahulu ditentukan persyaratan analisis, yaitu persyaratan normalitas dan homogenitas. Uji persyaratan normalitas menggunakan uji Liliefors, dan uji persyaratan homogenitas menggunakan uji Fisher dan uji Bartlett. Uji Anava 2 jalur ternyata signifikan interaksinya, maka diadakan uji lanjut dengan uji Scheffe' untuk menguji perbandingan ganda antar sel, sebab besar sampel dari masing-masing sel dalam rancangan penelitian tidak sama (n tidak sama).

Sebelum data hasil penelitian dianalisis menggunakan teknik statistik infrensial, terlebih dahulu ditentukan persyaratan analisis, yaitu persyaratan normalitas dan homogenitas. Uji persyaratan normalitas menggunakan uji Liliefors, dan uji persyaratan homogenitas menggunakan uji Fisher dan uji Bartlett.

Uji Anava 2 jalur ternyata signifikan interaksinya, maka diadakan uji lanjut dengan uji Scheffe' untuk menguji perbandingan ganda antar sel, sebab besar sampel dari masingmasing sel dalam rancangan penelitian tidak sama (n tidak sama). Selanjutnya, untuk keperluan pengujian hipotesis, dirumuskan hipotesis statistik sebagai berikut:

1. Hipotesis Pertama

$$
\text { Ho : } \mu \mathrm{A} 1=\mu \mathrm{A} 2
$$$$
\mathrm{Ha}: \mu \mathrm{A} 1>\mu \mathrm{A} 2
$$

2. Hipotesis Kedua

Ho : $\mu \mathrm{B} 1=\mu \mathrm{B} 2$

$\mathrm{Ha}: \mu \mathrm{B} 1>\mu \mathrm{B} 2$

3. Hipotesis Ketiga

Ho ; $\mathrm{A}><\mathrm{B}=0$

$\mathrm{Ha} ; \mathrm{A}><\mathrm{B} \neq 0$

Keterangan :

$\mu \mathrm{A} 1=$ rata-rata hasil belajar bahasa Inggris siswa yang dibelajarkan dengan strategi pembelajaran kontekstual.

$\mu \mathrm{A} 2=$ rata-rata hasil belajar bahasa Inggris siswa yang dibelajarkan dengan strategi pembelajaran ekspositori.

$\mu \mathrm{B} 1$ = rata-rata hasil belajar bahasa Inggris siswa yang memiliki kemampuan berpikir verbal Tinggi.

$\mu \mathrm{B} 2=$ rata-rata hasil belajar bahasa Inggris siswa yang memiliki kemampuan berpikir verbal Rendah.

\section{HASIL PENELITIAN}

Data yang telah dikumpulkan melalui penelitian ini disesuaikan dengan keperluan analisis data yang tercantum dalam rancangan penelitian yang bertujuan untuk menunjukkan gambaran umum mengenai penyebaran atau distribusi data. Data tersebut dapat digunakan sebagai dasar keputusan statistik untuk pengujian hipotesis. 
Tabel 1. Deskripsi Data Hasil Penelitian

\begin{tabular}{|c|c|c|c|c|c|c|}
\hline $\mathrm{SP}$ & \multicolumn{2}{|c|}{$\begin{array}{l}\text { Kontekstual } \\
\text { (A1) }\end{array}$} & \multicolumn{2}{|c|}{$\begin{array}{l}\text { Ekspositori } \\
\text { (A2) }\end{array}$} & \multicolumn{2}{|r|}{$\begin{array}{c}\text { Total } \\
\Sigma\end{array}$} \\
\hline $\begin{array}{l}\text { Tinggi } \\
\text { (B1) }\end{array}$ & & $\begin{array}{l}=26 \\
=24.35 \\
=633 \\
=15511\end{array}$ & $\begin{array}{l}\frac{N}{X} \\
\Sigma X \\
\Sigma X^{2}\end{array}$ & $\begin{array}{l}=15 \\
=21.07 \\
=316 \\
=6710\end{array}$ & $\begin{array}{l}\frac{N}{X} \\
\Sigma X \\
\Sigma X^{2}\end{array}$ & $\begin{array}{l}=41 \\
=45.42 \\
=949 \\
=22221\end{array}$ \\
\hline $\begin{array}{c}\text { Rendah } \\
\text { (B2) }\end{array}$ & & $\begin{array}{l}=14 \\
=17.71 \\
=234 \\
=3934\end{array}$ & $\begin{array}{l}\frac{N}{X} \\
\Sigma X \\
\Sigma X^{2}\end{array}$ & $\begin{array}{l}=25 \\
=18.16 \\
=454 \\
=8328\end{array}$ & $\begin{array}{l}\frac{N}{X} \\
\Sigma X \\
\Sigma X^{2}\end{array}$ & $\begin{array}{l}=39 \\
=34.87 \\
=688 \\
=12262\end{array}$ \\
\hline $\begin{array}{c}\text { Total } \\
\Sigma\end{array}$ & & $\begin{array}{l}=40 \\
=41.06 \\
=867 \\
=19445\end{array}$ & $\begin{array}{l}\frac{N}{X} \\
\Sigma X \\
\Sigma X^{2}\end{array}$ & $\begin{array}{l}=40 \\
=39.23 \\
=770 \\
=15038\end{array}$ & $\begin{array}{l}\frac{\mathrm{N}}{\mathrm{X}} \\
\Sigma \mathrm{X} \\
\Sigma \mathrm{X}^{2}\end{array}$ & $\begin{array}{l}=80 \\
=80.29 \\
=1637 \\
=34483\end{array}$ \\
\hline
\end{tabular}

Pengujian hipotesis dilakukan berdasarkan data yang diperoleh di lapangan. Hipotesis dalam penelitian ini diuji dengan menggunakan analisis varians (Anava) dua jalur. Ringkasan hasil perhitungan analisis varians (Anava) dua jalur dapat dilihat pada tabel bawah ini.

Tabel 2. Rangkuman hasil Anava secara keseluruhan terhadap hasil belajar Bahasa Inggris

\begin{tabular}{|c|c|c|c|c|c|}
\hline Sumber Variansi & JK & $\mathrm{dk}$ & RJK & $\mathrm{F}_{\text {hitung }}$ & $\mathrm{F}_{\text {table }}$ \\
\hline $\begin{array}{c}\text { Kemampuan berpikir verbal } \\
\text { Siswa }\end{array}$ & 506.79 & 1 & 506.79 & 148.62 & \multirow{3}{*}{3,97} \\
\hline Strategi Pembelajaran & 117.61 & 1 & 117.61 & 34.49 & \\
\hline $\begin{array}{l}\text { Interaksi Antara Strategi Pembelajaran Dan } \\
\text { Kemampuan berpikir verbal Rendah Siswa }\end{array}$ & 201.45 & 1 & 201.45 & 59.08 & \\
\hline $\begin{array}{l}\text { Dalam Kelompok } \\
\text { (Kekeliruan) }\end{array}$ & 160.03 & 76 & 3.41 & & \\
\hline Total & 985.88 & 79 & & & \\
\hline
\end{tabular}

Perbedaan Hasil Belajar Bahasa Inggris Antara Siswa Yang Memperoleh Strategi Pembelajaran Kontekstual Dan Strategi Pembelajaran Ekspositori.

Dari tabel rangkuman hasil analisis varians di atas diperoleh $\mathrm{F}_{\text {hitung }}$ sebesar 34,49 , sedangkan $\mathrm{F}_{\text {table }}$ dengan derajat kebebasan $(\mathrm{dk})$ $=1,76$ pada taraf $\propto=5 \%$ adalah sebesar 3,97. Jadi dari hasil perhitungan diperoleh $\mathrm{F}_{\text {hitung }}$ lebih besar dari $F_{\text {table }}$ yaitu 34,49> 3,97 sehingga hipotesis nol (Ho) ditolak. Hal ini berarti bahwa hasil belajar bahasa Inggris siswa yang dibelajarkan dengan strategi pembelajaran kontekstual lebih tinggi dari pada siswa yang diajarkan dengan strategi pembelajaran ekspositori teruji kebenarannya.

Perbedaan Hasil Belajar Bahasa Inggris Antara Siswa Yang Memiliki Kemampuan Berpikir Verbal Tinggi Dan Kemampuan Berpikir Verbal Rendah.
Dari tabel di atas dapat diketahui bahwa harga nilai $\mathrm{F}_{\text {hitung }}=148,62$ sedangkan $\mathrm{F}_{\text {table }}$ dengan derajat kebebasan $(\mathrm{dk})=(1,76)$ pada taraf $\propto=5 \%$ adalah 3,97. Hasil ini menunjukkan bahwa $\mathrm{F}_{\text {hitung }}=148,62>\mathrm{F}_{\text {table. }}=$ 3,97 sehingga Hipotesis Nol (Ho) ditolak. Hal ini berarti bahwa hipotesis penelitian yang menyatakan bahwa siswa yang memiliki kemampuan berpikir verbal tinggi memperoleh hasil belajar bahasa Inggris yang lebih tinggi dari pada siswa yang memiliki kemampuan berpikir verbal rendah teruji kebenarannya.

\section{Interaksi Antara Strategi Pembelajaran dan Kemampuan Berpikir Verbal Siswa Dalam Mempengaruhi Hasil Belajar Bahasa Inggris Berdasarkan hasil analisis varians (Anava) dua jalur tentang interaksi, didapat harga nilai $\mathrm{F}_{\text {hitung }}=59,08$ dengan derajat kebebasan $(\mathrm{dk})=1,76$ pada taraf $\propto=5 \%$ adalah 3,97. Hasil ini menunjukkan bahwa}


$F_{\text {hitung }}=59,08>F_{\text {table. }}=3,97$ sehingga Hipotesis Nol (Ho) ditolak. Hal ini berarti bahwa hipotesis penelitian yang menyatakan bahwa terdapat interaksi antara strategi pembelajaran dan kemampuan berpikir verbal dalam memberikan pengaruh terhadap hasil belajar bahasa Inggris teruji kebenarannya.
Untuk melihat bentuk interaksi antara strategi pembelajaran dan kemampuan berpikir verbal dalam mempengaruhi hasil belajar bahasa Inggris, maka uji lanjutan dengan teknik analisis uji scheffe guna mengetahui rata-rata hasil belajar sampel mana yang berbeda. Hasil uji lanjut tersebut dapat dilihat pada tabel 3 berikut :

Tabel 19. Ringkasan Hasil Perhitungan Uji Scheffe'

\begin{tabular}{|l|l|c|c|c|}
\hline \multicolumn{2}{|c|}{ Hipotesis Statistik } & \multirow{2}{*}{$\mathrm{F}_{\text {hitung }}$} & \multicolumn{2}{c|}{$\mathrm{F}_{\text {tabel }}$} \\
\cline { 4 - 5 } & & & $\alpha=5 \%$ & $\alpha=1 \%$ \\
\hline Ho: $\mu \mathrm{A}_{1} \mathrm{~B}_{1}=\mu \mathrm{A}_{2} \mathrm{~B}_{1}$ & $\mathrm{Ha}: \mu \mathrm{A}_{1} \mathrm{~B}_{1}>\mu \mathrm{A}_{2} \mathrm{~B}_{1}$ & 48,32 & 2,72 & 4.05 \\
\hline $\mathrm{Ho}: \mu \mathrm{A}_{2} \mathrm{~B}_{2}=\mu \mathrm{A}_{1} \mathrm{~B}_{2}$ & $\mathrm{Ha}: \mu \mathrm{A}_{1} \mathrm{~B}_{2}>\mu \mathrm{A}_{2} \mathrm{~B}_{2}$ & 8,29 & 2,72 & 4.05 \\
\hline $\mathrm{Ho}: \mu \mathrm{A}_{1} \mathrm{~B}_{1}=\mu \mathrm{A}_{1} \mathrm{~B}_{2}$ & $\mathrm{Ha}: \mu \mathrm{A}_{1} \mathrm{~B}_{1}>\mu \mathrm{A}_{1} \mathrm{~B}_{2}$ & 48,32 & 2,72 & 4.05 \\
\hline $\mathrm{Ho}: \mu \mathrm{A}_{2} \mathrm{~B}_{1}=\mu \mathrm{A}_{2} \mathrm{~B}_{2}$ & $\mathrm{Ha}: \mu \mathrm{A}_{2} \mathrm{~B}_{1}>\mu \mathrm{A}_{2} \mathrm{~B}_{2}$ & 4,89 & 2,72 & 4.05 \\
\hline Ho: $\mu \mathrm{A}_{1} \mathrm{~B}_{1}=\mu \mathrm{A}_{2} \mathrm{~B}_{2}$ & $\mathrm{Ha}: \mu \mathrm{A}_{1} \mathrm{~B}_{1}>\mu \mathrm{AB}_{2}$ & 81,23 & 2,72 & 4.05 \\
\hline Ho $: \mu \mathrm{A}_{1} \mathrm{~B}_{2}=\mu \mathrm{A}_{2} \mathrm{~B}_{1}$ & $\mathrm{Ha}: \mu \mathrm{A}_{1} \mathrm{~B}_{2}>\mu \mathrm{A}_{2} \mathrm{~B}_{1}$ & 16,07 & 2,72 & 4.05 \\
\hline
\end{tabular}

Kriteria penerimaan jika : $\mathbf{F}_{\text {hitung }}>\mathbf{F}_{\text {table }}$, maka teruji secara signifikan.

Hasil pengujian hipotesis di atas, menunjukkan adanya interaksi antara strategi pembelajaran dan kemampuan berpikir verbal terhadap hasil belajar bahasa Inggris siswa.

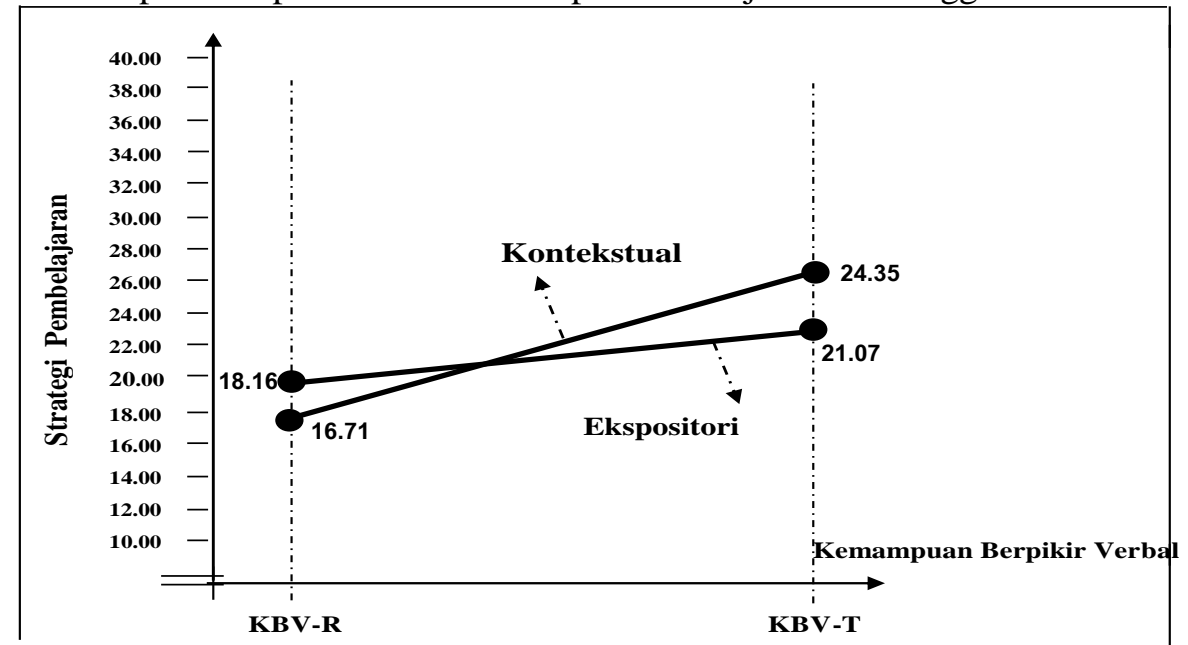

Gambar 1. Model Interaksi Antara Strategi Pembelajaran dan Kemampuan Berpikir Verbal Terhadap Hasil Belajar Bahasa Inggris Siswa

\section{PEMBAHASAN}

Pembelajaran bahasa Inggris akan memberikan perolehan hasil belajar yang lebih baik melalui belajar bermakna, yakni pembelajaran yang mengaitkan antara kesiapan struktur kognitif atau pengalaman belajar dengan pengetahuan baru yang akan diterima siswa dengan cara menciptakan lingkungan belajar yang merangsang untuk pembelajaran kreatif. Mengingat luasnya cakupan dan objek pelajaran bahasa Inggris, maka dibutuhkan siswa yang memiliki kemampuan verbal yang tinggi, sebab siswa yang memiliki kemampuan verbal tinggi akan senantiasa termotivasi dan berusaha untuk meningkatkan atau mempertahankan kemampuannya semaksimal mungkin dengan menggunakan standar keunggulan dengan cara menciptakan dan mengidentifikasi alternatif-alternatif pemecahan masalah, mampu untuk melakukan berbagai hal serta lancar dalam mengemukakan gagasangagasannya. Siswa dengan kemampuan verbal tinggi dapat dengan cepat beradaptasi, menyesuaikan apa-apa yang diketahui dengan apa-apa yang akan dipelajarinya dalam penyelesaian soal-soal bahasa Inggris.

Siswa dengan kemampuan berpikir verbal tinggi memiliki kemampuan dalam merangkai, mengaitkan, dan menghubungkan materi-materi pelajaran yang telah dipelajari 
dengan materi-materi pelajaran yang akan dipelajari. Siswa yang memiliki kemampuan berpikir verbal tinggi mampu memberikan pemahaman yang benar terhadap orang atau siswa lain sesuai dengan makna yang akan disampaikan. Dengan kemampuan berpikir verbal tinggi, siswa mampu berkomunikasi secara efektif, baik secara lisan maupun tulisan. Kemampuan tersebut melahirkan siswa yang mampu menciptakan dan mengidentifikasi alternatif-alternatif pemecahan masalah, mampu untuk melakukan berbagai hal, serta lancar dalam mengemukakan gagasan-gagasannya. Siswa dengan kemampuan verbal tinggi dapat dengan cepat beradaptasi, menyesuaikan apaapa yang diketahui dengan apa-apa yang akan dipelajarinya dalam penyelesaian soal-soal bahasa Inggris agar mampu memberikan perolehan hasil bahasa Inggris yang lebih maksimal.

Kemampuan berpikir verbal tinggi sangat bermanfaat bagi siswa dalam memahami dan merangkai materi-materi pelajaran agar saling berhubungan, sehingga siswa mampu untuk menemukan ide, gagasan, dan menemukan alternatif-alternatif pemecahan masalah-masalah belajarnya, sekaligus memenuhi kebutuhan-kebutuhan belajarnya guna mencapai hasil belajar yang lebih maksimal. Pembelajaran kontekstual akan lebih bermakna bagi siswa dengan kemampuan verbal tinggi, karena proses pembelajaran akan berlangsung dalam bentuk kegiatan bekerja dan mengalami, bukan transfer pengetahuan dari guru ke siswa. Untuk pembelajaran kontekstual dibutuhkan kemampuan berfikir verbal tinggi guna menguraikan sesuatu hal secara terperinci, selalu terdorong untuk tahu lebih banyak tentang sesuatu, merasa tertantang untuk menghadapi situasi yang sulit dan berupaya secara aktif untuk mengatasi soal-soal yang diberikan untuk memperoleh hasil belajar bahasa Inggris yang lebih baik sesuai dengan tujuan instruksional yang telah ditetapkan.

Bagi siswa dengan kemampuan berpikir verbal tinggi, jika dibelajarkan dengan strategi pembelajaran ekspositori akan memperoleh hasil belajar yang kurang maksimal, sebab pembelajaran ekspositori berpusat pada guru (teacher centered), dimana guru berfungsi sebagai sumber utama pembelajaran, artinya siswa tidak diberdayakan atau cenderung hanya menunggu dan memperoleh keterampilan dan pengetahuan yang berdasarkan hafalan (rote learning). Siswa dengan kemampuan verbal tinggi akan merasa bosan jika diajar dengan strategi pembelajaran ekspositori, karena siswa tidak diberi kesempatan untuk membangung (mengkonstruk) sendiri konsep-konsep yang diajarkan. Pada pembelajaran ekspositori tekanan utama pembelajaran untuk seluruh anggota kelas. Strategi pembelajaran ekspositori mengurangi kreativitas siswa dan kecerdasan dalam berpikir untuk memecahkan masalah-masalah dalam pembelajaran bahasa Inggris.

Pembelajaran kontekstual lebih efektif dalam meningkatkan hasil belajar siswa dengan dengan kemampuan berpikir verbal tinggi. Pada pembelajaran kontekstual terhadap siswa dengan kemampuan verbal tinggi ini adalah terjadinya pertukaran informasi dan pengetahuan antar siswa satu sama lainnya. Hal ini terjadi sebab siswa dengan kemampuan verbal tinggi memberikan peluang kepada siswa tersebut untuk membentuk atau melakukan pertukaran informasi dan pengetahuan antar siswa, sehingga pertukaran ilmu pengetahuan, informasi, dan keterampilan antar sesama siswa ini menciptakan siswa-siswa yang memiliki ilmu pengetahuan, informasi, dan keterampilan yang relatif sama atau setara. Kondisi inilah yang sangat membantu siswa dalam memahami dan merangkai materi-materi pelajaran agar saling berhubungan, sehingga siswa mampu untuk menemukan ide, gagasan, dan menemukan alternatif-alternatif pemecahan masalah-masalah belajarnya, sekaligus memenuhi kebutuhan-kebutuhan belajarnya guna mencapai hasil belajar yang lebih maksimal.

Bagi siswa yang memiliki kemampuan berpikir verbal rendah jika dibelajarkankan dengan strategi pembelajaran kontekstual, akan mengalami kesulitan untuk membangun atau mengkonstruk pengetahuan dan keterampilan bahasa Inggris yang dibutuhkannya, sebab siswa dengan kemampuan berpikir rendah memiliki tingkat kecepatan yang rendah dalam memahami, dan memaknai materi-materi esensial pelajaran bahasa Inggris. Struktur kognitif siswa dengan kemampuan berpikir verbal rendah membutuhkan waktu dan proses pembelajaran yang lebih lama untuk mencema suatu materi pelajaran bahasa Inggris yang disajikan. Siswa dengan kemampuan berpikir verbal rendah akan mengalami kesulitankesulitan dalam menyelesaikan soal-soal bahasa Inggris yang dihadapinya, sebab siswa tersebut memiliki kemampuan yang kurang baik dalam 
berkomunikasi, dan bekerjasama dengan temantemannya dalam menemukan solusi permasalahan belajarnya.

Bagi siswa dengan kemampuan berpikir verbal tinggi, jika dibelajarkan dengan strategi pembelajaran ekspositori akan memperoleh hasil belajar yang kurang maksimal, sebab pembelajaran ekspositori berpusat pada guru (teacher centered), dimana guru berfungsi sebagai sumber utama pembelajaran, artinya siswa tidak diberdayakan atau cenderung hanya menunggu dan memperoleh keterampilan dan pengetahuan yang berdasarkan hafalan (rote learning). Siswa dengan kemampuan verbal tinggi akan merasa bosan jika diajar dengan strategi pembelajaran ekspositori, karena siswa tidak diberi kesempatan untuk membangun (mengkonstruk) sendiri konsep-konsep yang diajarkan. Pada pembelajaran ekspositori tekanan utama pembelajaran untuk seluruh anggota kelas. Strategi pembelajaran ekspositori mengurangi kreativitas siswa dan kecerdasan dalam berpikir untuk memecahkan masalah-masalah dalam pembelajaran bahasa Inggris. Guru mengajar kepada seluruh siswa tanpa memandang aspek individual, biologis, intelektual, dan psikologis siswa. Guru bertindak sebagai satu-satunya sumber belajar dan sekaligus sebagai penyaji isi pelajaran. Pembelajaran seperti ini kurang memberdayakan siswa dalam mengamati dan mengarahkan siswa kepada pembelajaran secara efektif, sehingga siswa tidak merasakan dan tidak menghasilkan bayangan-bayangan mental dan visualisasi detail dalam benaknya. Perolehan hasil belajar bahasa Inggris seperti ini hanya mampu bertahan dalam jangka waktu relatif singkat, karena pengetahuan dan keterampilan yang diperoleh bukan dengan cara mengalami secara langsung dalam proses pembelajaran, sehingga siswa tidak aktif dan kreatif.

Pembelajaran kontekstual akan lebih bermakna bagi siswa dengan kemampuan verbal tinggi, karena proses pembelajaran akan berlangsung dalam bentuk kegiatan bekerja dan mengalami, bukan transfer pengetahuan dari guru ke siswa. Untuk pembelajaran kontekstual dibutuhkan kemampuan untuk mengaitkan materi-materi pelajaran yang telah dipelajari dengan materi-materi pelajaran selanjutnya. Dengan kata lain, pembelajaran kontekstual membutuhkan siswa yang memiliki kemampuan verbal tinggi, sehingga siswa mampu memberikan pemahaman yang benar terhadap orang atau siswa lain sesuai dengan makna yang akan disampaikan dan mampu berkomunikasi secara efektif, baik secara lisan maupun tulisan. Kemampuan tersebut melahirkan siswa yang mampu menciptakan dan mengidentifikasi alternatif-alternatif pemecahan masalah, mampu untuk melakukan berbagai hal, serta lancar dalam mengemukakan gagasan-gagasannya. Selanjutnya, siswa dengan kemampuan verbal tinggi dapat menguraikan sesuatu hal secara terperinci, selalu terdorong untuk tahu lebih banyak tentang sesuatu, merasa tertantang untuk menghadapi situasi yang sulit dan berupaya secara aktif untuk mengatasi soal-soal yang diberikan untuk memperoleh hasil belajar bahasa Inggris yang lebih baik sesuai dengan tujuan instruksional yang telah ditetapkan.

Sebaliknya, untuk siswa yang memiliki kemampuan berpikir verbal rendah, strategi pembelajaran ekspositori lebih efektif diterapkan dalam memperoleh hasil belajar yang lebih baik, sebab strategi pembelajaran ekspositori adalah suatu strategi pembelajaran yang berpusat pada guru (teacher centred). Artinya, proses pembelajaran didominasi oleh guru, dimana guru berperan sebagai narasumber dan merangsang siswa untuk mengeluarkan ideide atau konsep dengan pertanyaan-pertanyaan yang mudah dipahami dalam memecahkan masalah. Di akhir pembelajaran, dilakukan kegiatan tanya jawab, memberikan tugas kepada siswa untuk membuat rangkuman pelajaran yang baru diikuti dibuku catatan masing-masing dengan memberitahukan terlebih dahulu materi-materi penting pada pembelajaran yang baru dilakukan. Dengan demikian, meskipun siswa memiliki kemampuan berpikir verbal rendah, siswa tersebut cenderung dapat menerima dan memahami makna dan esensi materi-materi penting pelajaran tersebut, sebab guru senantiasa mengarahkan dan membimbing siswa untuk memperoleh hasil belajar sesuai dengan tujuan instruksional yang telah ditetapkan. Siswa diarahkan untuk membuat rangkuman secara individual didampingi oleh guru untuk mengetahui secara langsung apa yang dikerjakan siswa dalam membuat rangkuman, dan apabila siswa kurang mampu untuk mengidentifikasi materi yang harus dirangkum, maka guru mengarahkannya. Oleh karena itu, perolehan pengetahuan dan keterampilan secara sistematis yang bersumber dari guru sebagai sumber utama pengetahuan 
dan sekaligus penyaji isi materi pelajaran masih harus tetap dipertahankan.

Pembelajaran kontekstual lebih efektif dalam meningkatkan hasil belajar siswa dengan kemampuan berpikir verbal tinggi. Pada pembelajaran seperti ini, siswa mampu meningkatkan kemampuannya untuk berkomunikasi secara efektif, akan memberikan peluang kepada siswa tersebut untuk membentuk atau melakukan pertukaran informasi dan pengetahuan antar siswa satu sama lainnya, yang pada gilirannya akan tiba pada saling pengertian yang mendalam. Proses terpenting dalam pembelajaran kontekstual terhadap siswa dengan kemampuan verbal tinggi ini adalah terjadinya pertukaran informasi dan pengetahuan antar siswa satu sama lainnya. Hal ini terjadi sebab siswa dengan kemampuan verbal tinggi memberikan peluang kepada siswa tersebut untuk membentuk atau melakukan pertukaran informasi dan pengetahuan antar siswa, sehingga pertukaran ilmu pengetahuan, informasi, dan keterampilan antar sesama siswa ini menciptakan siswa-siswa yang memiliki ilmu pengetahuan, informasi, dan keterampilan yang relatif sama atau setara. Kondisi inilah yang sangat membantu siswa dalam memahami dan merangkai materi-materi pelajaran agar saling berhubungan, sehingga siswa mampu untuk menemukan ide, gagasan, dan menemukan alternatif-alternatif pemecahan masalah-masalah belajarnya, sekaligus memenuhi kebutuhan-kebutuhan belajarnya guna mencapai hasil belajar yang lebih maksimal.

Sedangkan bagi siswa dengan kemampuan verbal rendah lebih efektif jika dibelajarkan dengan strategi pembelajaran ekspositori. Strategi pembelajaran ekspositori adalah suatu strategi pembelajaran yang berpusat pada guru (teacher centred), artinya, proses pembelajaran didominasi oleh guru, dimana guru berperan sebagai narasumber dan merangsang siswa untuk mengeluarkan ide-ide atau konsep dengan pertanyaan-pertanyaan yang mudah dipahami dalam memecahkan masalah. Di akhir pembelajaran, dilakukan kegiatan tanya jawab, memberikan tugas kepada siswa untuk membuat rangkuman pelajaran yang baru diikuti dibuku catatan masing-masing dengan memberitahukan terlebih dahulu materi-materi penting pada pembelajaran yang baru dilakukan. Dengan demikian, meskipun siswa memiliki kemampuan berpikir verbal rendah, siswa tersebut cenderung dapat menerima dan memahami makna dan esensi materi-materi penting pelajaran tersebut, sebab guru senantiasa mengarahkan dan membimbing siswa untuk memperoleh hasil belajar sesuai dengan tujuan instruksional yang telah ditetapkan. Akan tetapi, siswa dengan kemampuan verbal rendah pada dasarnya memiliki kesulitan dalam menyampaikan, menuangkan, dan mengorganisasikan buah pikirannya dalam bentuk bahasa lisan maupun tulisan, sebab siswa tersebut tidak memiliki wawasan, pengetahuan, dan penguasaan tentang kata-kata dan kalimat dalam melakukan komunikasi yang efektif. Siswa dengan kemampuan berpikir verbal rendah akan merasa kesulitan untuk menciptakan dan menghasilkan kata-kata dan kalimat-kalimat secara tepat, selanjutnya akan merasa kesulitan dalam memenuhi kebutuan-kebutuhan belajarnya.

Sedangkan siswa dengan kemampuan berpikir verbal tinggi, jika dibelajarkan dengan strategi pembelajaran ekspositori akan memperoleh hasil belajar yang kurang maksimal, sebab pembelajaran ekspositori berpusat pada guru (teacher centered), dimana guru berfungsi sebagai sumber utama pembelajaran, artinya siswa tidak diberdayakan atau cenderung hanya menunggu dan memperoleh keterampilan dan pengetahuan yang berdasarkan hafalan (rote learning). Siswa dengan kemampuan verbal tinggi akan merasa bosan jika diajar dengan strategi pembelajaran ekspositori, karena siswa tidak diberi kesempatan untuk membangun sendiri konsepkonsep yang diajarkan. Akan tetapi, kemampuan verbal tinggi yang dimiliki siswa secara lambat laun menciptakan suasana kelas dimana siswa saling memberikan peluang satu sama lain untuk membentuk atau melakukan pertukaran informasi dan pengetahuan antar siswa, sehingga pertukaran ilmu pengetahuan, informasi, dan keterampilan antar sesama siswa ini menciptakan siswa-siswa yang memiliki ilmu pengetahuan, informasi, dan keterampilan yang relatif sama atau setara. Kondisi inilah yang sangat membantu siswa dalam memahami dan merangkai materi-materi pelajaran agar saling berhubungan, sehingga siswa mampu untuk menemukan ide, gagasan, dan menemukan alternatif-alternatif pemecahan masalah-masalah belajarnya, sekaligus memenuhi kebutuhan-kebutuhan belajarnya 
guna mencapai hasil belajar yang lebih maksimal.

Siswa yang memiliki kemampuan berpikir verbal rendah yang dibelajarkan dengan strategi pembelajaran kontekstual memperoleh hasil belajar bahasa Inggris yang lebih tinggi dibandingkan dengan siswa dengan kemampuan verbal tinggi dibelajarkan dibandingkan dengan strategi pembelajaran ekspositori. Artinya, meskipun siswa memiliki kemampuan verbal rendah, jika dibelajarkan dengan strategi pembelajaran kontekstual, maka siswa akan berpeluang untuk memperoleh hasil belajar bahasa Inggris yang lebih baik. Hal tersebut terjadi karena strategi pembelajaran kontekstual adalah suatu bentuk strategi pembelajaran yang mempunyai landasan filosofi konstruktivisme, yakni proses belajar mengajar akan lebih bermakna jika anak "menemukan sendiri" apa yang dipelajarinya, bukan "mengetahuinya" dari orang lain. Hasil pembelajaran dengan strategi pembelajaran kontekstual lebih bermanfaat bagi siswa, karena proses pembelajaran berlangsung alamiah dalam bentuk kegiatan bekerja dan mengatami, bukan transfer pengetahuan dari guru ke siswa.

\section{PENUTUP}

Berdasarkan hasil pengujian hipotesis seperti yang telah dikemukakan, dapat ditarik beberapa kesimpulan dari hasil penelitian di SMP Negeri 1 Selesai, yaitu :

1. Hasil belajar bahasa Inggris siswa yang diajarkan dengan strategi pembelajaran kontekstual lebih tinggi dibandingkan dengan siswa yang diajarkan dengan strategi pembelajaran ekspositori.

2. Siswa yang memiliki kemampuan berpikir verbal tinggi memperoleh hasil belajar bahasa Inggris lebih tinggi dibandingkan dengan siswa yang memiliki kemampuan berpikir verbal rendah.

3. Terdapat interaksi antara strategi pembelajaran dan kemampuan berpikir verbal terhadap hasil belajar bahasa Inggris siswa SMP Negeri 1 Selesai. Perbedaan pengaruh tersebut adalah: (a) Hasil belajar bahasa Inggris siswa jika diajar dengan menggunakan strategi pembelajaran kontekstual lebih tinggi dibandingkan dengan siswa yang diajarkan dengan strategi pembelajaran ekspositori untuk siswa yang memiliki kemampuan berpikir verbal tinggi, (b) Hasil belajar bahasa Inggris siswa jika diajar dengan menggunakan strategi pembelajaran ekspositori lebih tinggi dibandingkan dengan siswa yang diajarkan dengan menggunakan strategi pembelajaran kontekstual untuk siswa yang memiliki kemampuan berpikir verbal rendah. (c) Hasil belajar bahasa Inggris siswa dengan kemampuan berpikir verbal tinggi jika diajar menggunakan strategi pembelajaran kontekstual lebih tinggi dibandingkan dengan siswa yang memiliki kemampuan berpikir verbal rendah. (d) Hasil belajar bahasa Inggris siswa dengan kemampuan berpikir verbal tinggi jika dibelajarkan dengan menggunakan strategi pembelajaran ekspositori memperoleh hasil belajar bahasa Inggris yang lebih tinggi dibandingkan dengan siswa yang memiliki kemampuan berpikir verbal rendah, (e) Hasil belajar bahasa Inggris siswa dengan kemampuan berpikir verbal tinggi jika diajar menggunakan strategi pembelajaran kontekstual lebih tinggi dibandingkan dengan siswa yang memiliki kemampuan berpikir verbal rendah yang diajar dengan menggunakan strategi pembelajaran ekspositori. (f) Hasil belajar bahasa Inggris siswa yang memiliki kemampuan berpikir verbal rendah, lebih tinggi jika menggunakan strategi pembelajaran ekspositori dibandingkan dengan menggunakan strategi pembelajaran kontekstual dengan kemampuan berpikir verbal rendah .

\section{DAFTAR PUSTAKA}

Arikunto, S. (2002). Prosedur Penelitian, Suatu Pendekatan Praktek. Jakarta: Rineka Cipta.

Atkinson, Rita L dan Richard C Hilgard. (1983). Pengantar Psikologi Edisi ke Delapan Jilid I. Jakarta : Erlangga.

Atmadi, A. dkk. (2000). Transformasi Pendidikan Memasuki Millenium Ketiga. Yogyakarta: Kanisius.

Ausubel, D.P, (1983). The Psikologi of Meaningful Verbal Learning, New York: Grune \& Staton

Balitbang, Depdiknas. (2002). Kurikulum Berbasis Kompetensi. Jakarta: Pusat Kurikulum Balitbang Depdiknas.

Bloom, B.S. et all (1982)., Taxonomy of Education Objectives: The Classification of Educational Goals. Handbook I: Cognitive Domain. New York: Logman Inc. 
DePorter, B. dan Hernacki, (1992)., Quantum Learning (Penerjemah: Alwiyah Abdurrahman), Bandung: Kaifa.

Dick, W., and Carey, L., (2005). The Systematic Design of Instruction. London: Scott, Foresman and Company.

Dimyati dan Mudjiono, (1999)., Belajar dan Pembelajaran. Jakarta: Rineka Cipta.

Gagne, R.M. (1977). The Condition of Learning $3^{\text {rd }}$ edition, New York: Holt Rinehart and Winston Inc

Gagne, R.M., and Briggs L.J. (1974). Principles of InstructionL Design. New York: Holt Renehart and Winston Inc.

Gerlach, Vernon. S. Ely, Donald. P. (1980). Teaching And Media.A Systematic Approuch. New Jersey: Prentice Hall Inc.

Givon, T. (1995). Functionalism and Grammar. Philadelpia: John Benjamins Publishing.

Gregore, A. (1982). An Adult's to Style, Gabriel System, Maynard.

Gunawan, (2004), Born to be a Genius. Jakarta : Gramedia.

Heinich, RE. (1996). Instructional Media and Technologies for Learning $5^{\text {th }}$. New Jersey: Enggle Wood Prentice Hall.

Hoyle, Eric. 1980. The Role of The Teachers. London: Lowe and Brydone.

Huddlestone, Rodney. 1984. Introduction to the Grammar of English. Great Britain: Cambridge University Press.

Irianto, Jusuf. (2000). Model Sosial Inquiry Dalam Interaksi Belajar Mengajar Sejarah. Madani. Vol 2 No. 2, hal. 16-20

Joyce, Bruce dan Weil, Marsha, (1986)., Models of Teaching. New Jersey: Prentice Hall Inc.

Kasihani, K., Latief, A., Nurhadi. (2002). Pembelajaran Berbasis CTL (Contekstual Teaching and Learning). Makalah disampaikan pada Kegiatan Sosialisasi CTL untuk Dosen-Dosen UN. Malang

Keefe, (1987). Learning Styles: Theory and Practice. Reston, Virginia: National Associaton of Secondary School Principles (NASSP).

Lubis, Syahron, 2002. Sistem Pengembangan Kosakata bahasa Inggris. Medan: FKIP UMSU.

Merrill, MD. (1991). "A Lesson Based on The Component Display Theory" Instruction Theories in Action. Reigeluth (ed). New Jersey: Lawrence Erlbaum Ass.
Messick, S. (1976). Individuality in Learning. San Fransisco: Freeman.

Nasution, S. (2000). Berbagai Pendekatan Dalam Proses Belajar Mengajar., Jakarta: Bumi Aksara.

Piaget J, (1970). Science of Education and the psychology of the child. New York: Wiley.

Ram, Morrman. 1981. Developing Reading Skills. Cambridge: Cambridge University Press.

Rezeki, Robbi. (2005). Pengaruh Strategi Pembelajaran Kontekstual Dan Kreativitas Terhadap Hasil Belajar Matematika SLTP Kecamatan Stabat. Tesis. Medan: Program Pascasarjana Universitas Negeri Medan.

Rogers, C (1982). Freedom To Learn for the 80's. Colombus: Charles E. Merrill

Romizowski, A.J. (1981). Design Instructional System, London: Kogan Page Ltd.

Sanjaya, Wina (2006). Strategi Pembelajaran, Jakarta: Prenada Media Group.

Semiawan, Conny R (2002). Belajar dan Pembelajaran Dalam Taraf Usia Dini. Jakarta: CV. Prehallindo.

Sibuea, Nurhalimah, (2006). "Pengaruh Strategi Pembelajaran dan Kemampuan Verbal Terhadap Hasil Belajar Bahasa Indonesia Siswa”. Tesis. Program Pascasarjana Universitas Negeri Medan.

Somantri, N.M. (2001), Menggagas Pembaharuan Pendidikan IPS. Bandung: Remaja Rosdakarya

Suryabrata, S. (2001). Pengukuran Dalam Psikologi Kepribadian, Jakarta: Rajawali. 